\section{Gifts to the Association}

Sir George Allen, secretary of the British Association for the Advancement of Science, has announced that, as a result of approaches to a small number of leading industrialists, a very substantial addition to the income of the Association for the next seven years has been obtained. $£ 40,000$ has already been received, giving an additional $\mathfrak{£} 8,000$ income for the coming year. It is now proposed to widen the appeal. Owing to the generosity of this same group of industrialists, it will be possible during the coming year to extend the Association's activities, and detailed plans for the future, which will include inter-meeting activities, are being discussed.

Endeavour Prizes

THE prizes awarded by the British Association for the 1957 Endeavour Essay Competition were presented by Prof. P. M. S. Blackett, on September 5, during the reception for exhibitioners. The competition is sponsored annually by Imperial Chemical Industries quarterly review Endeavour, and is limited to those under twenty-five years of age. Seventy-three entries were received, many from abroad, and the prize. winners were as follows: first prize of 50 guineas to Miss Ruth Kirkland, of Sydney, Australia, for an essay on "Particles in Plant and Animal Cells"; second prize of 25 guineas to Mr. R. B. Cain, of Smethwick, Staffordshire, for an essay on "Chemistry and the Conquest of Disease" ; third prize of 15 guineas to Mr. Charles Elliott, of Yorkshire, for an essay on "The International Geophysical Year". Two special prizes of 5 guineas were awarded to competitors under eighteen years of age. Mr. Geoffrey Benjamin, of Swansea, won one of these for an essay on "Particles in Plant and Animal Cells". Miss Dorothy Haas, of Birmingham, won the other for an essay on "Chemistry and the Conquest of Disease". An additional special prize of 3 guineas was awarded to Mr. Robin Jones, of Farnborough, for an essay of great merit.

\section{Atomic Energy Authority: Sir Leonard Owen, C.B.E.}

Sir LEONARD OWEN, director of engineering and deputy to the managing director of the Industrial Group of the Atomic Energy Authority, has been appointed managing director of the Industrial Group in succession to Sir Christopher Hinton, who has been appointed chairman of the Central Electricity Generating Board. Sir Leonard, who is sixty, has been engaged in the development of Britain's atomic energy programme since 1946, when ho was appointed director of engineering on the production side. In the following year he became assistant controller in the Atomic Energy Division's production side. When the United Kingdom Atomic Energy Authority was formed in 1954, he was made director of engineering and deputy managing director.
Sir Leonard was educated at Liverpool Collegiate School and the University of Liverpool, where he obtained the degree of M.Eng. During the First World War he was with the 6th King's Liverpool Regiment, and afterwards was successively with Brunner, Mond and Company and I.C.I. (Alkali), Ltd., with whom he was engaged in the Engineering Department, designing new chemical plant and additions to existing chemical plant. During 1940-45 he was on loan to the Ministry of Supply as Director of the Royal Filling Factories.

\section{University College of North Wales:}

Dr. R. C. Evans

Dr. Robert CaArles Evans, who has been appointed principal of the University College of North Wales from September 1, 1958, in succession to Sir Emrys Evans, was educated at Shrewsbury School and University College, Oxford, and has, since 1947, held surgical appointments at the Northern, Walton and Southern Hospitals, Liverpool. During 1943-46 he was on active service with the R.A.M.C. and was mentioned in dispatches. In 1953, as Hunterian professor, he lectured to the Royal College of Sur. geons on the physiological problems of adaptation to high altitudes. It is as a mountain climber that Dr. Evans is best known to the general public and particularly for his part in the Everest Expedition of 1953 , on which he was deputy leader and as 'quartermaster' had responsibility for organizing the stores. On that Expedition he reached the South Summit of Everest, but as leader of the Kanchenjunga Expedition of 1955 he reached the summit except for the last few feet, which, with characteristic consideration for the feelings of the Sikkimese, he left untouched. The conquest of Kanchenjunga is described in his book, "Kanchenjunga, the Untrodden Peak" (1956). Dr. Evans was awarded the Cullum Medal of the American Geographical Society in 1954, the Livingstone Medal of the Scottish Geographical Society in 1955 and the Founder's Medal of the Royal Geographical Society in 1956 .

\section{British Institution of Radio Engineers: Awards}

THE British Institution of Radio Engineers has recently awarded the following premiums to authors of papers published in its Journal during 1956 : Clerk Maxwell Premium, to Dr. K. D. Froome (Metrology Division of the National Physical Laboratory) for his paper, "Microwave Determinations of the Velocity of Light" ; Heinrich Hertz Premium, to Dr. A. G. Edwards (Associated Electrical Industries, Ltd.) for his paper, "The Effects of Atmospheries on Tuned Circuits"; Brabazon Premium to K. E. Harris, (Director 'of Research, Cossor Radar Ltd.), for his paper, "Some Problems of Secondary Surveillance Radar Systems"'; Louis Sterling Premium to Dr. A. van Weel (Philips Research Laboratories, Eindhoven), for his paper, "Some Remarks on the Radio- 